\title{
Design and field performance of power operated paddy weeder
}

\author{
P.U. Shahare, D. G. Jadhav, V.V. Aware and N.A. Shirsat
}

Received : 21.01.2020; Revised : 09.03.2020; Accepted : 22.03 .2020

See end of the Paper for authors' affiliation

Correspondence to :

D.G. Jadhav

Department of Farm Machinery and Power,

College of Agricultural Engineering and Technology, Dr. Balasaheb Sawant Konkan Krishi Vidyapeeth, Dapoli, Ratnagiri (M.S.) India Email: dnyaneshwargjadhav@ gmail.com
- ABSTRACT : Improper weed control methods can cause about 30-35 per cent reduction in crop yield. The power operated paddy weeder was designed and developed for weeding of paddy crops. In Konkan region, paddy is the major crop cultivated under wet land condition. The hand weeding method using labours is widely adopted at present for paddy. It is costly and drudgerious. Manually operated cono weeders are being used in some of the pockets of Konkan. It's capacity is less (upto $0.12-0.15 \mathrm{ha} /$ day) and its operation is also heavy due to its weight $(7.8 \mathrm{~kg})$. Therefore developed power weeder was designed. It was consisted of engine, gear box, propeller shaft, rotor with blade and main frame and float. The reduction gear box (ratio- 32.5:1) was used to reduce the speed to $200 \mathrm{rpm}$. The two types of rotors were developed viz., L shape blade and hexagonal serrated blade. The serrated blade has resulted into 9.41 per cent higher weeding efficiency than $\mathrm{L}$ shape blade. The L shape blade has resulted into 1.02 per cent minimum plant damage than serrated blade. The lowest fuel consumption of power weeder was found with of $\mathrm{L}$ shape blade as $0.576 \mathrm{l} / \mathrm{h}$ at $40 \mathrm{DAS}$ while the maximum fuel consumption was found on using of serrated blade as $0.68 \mathrm{l} / \mathrm{h}$ at $20 \mathrm{DAS}$. The maximum field capacity was found with $\mathrm{L}$ shape blade $(0.0266 \mathrm{ha} / \mathrm{h})$ than serrated blade $(0.0213 \mathrm{ha} / \mathrm{h})$ at $40 \mathrm{DAS}$ which is 30.39 per cent higher.

- KEY WORDS : Paddy weeder, L- shape blade, Serrated blade, Weeding efficiency, Plant damage

- HOW TO CITE THIS PAPER : Shahare, P.U., Jadhav, D. G., Aware, V.V. and Shirsat, N.A. (2020). Design and field performance of power operated paddy weeder. Internat. J. Agric. Engg., 13(1) : 121-127, DOI: 10.15740/HAS/IJAE/13.1/121-127. Copyright@ 2020: Hind Agri-Horticultural Society. 